\title{
Description of Human-Derived Centers for Disease Control Coryneform Group 2 Bacteria as Actinomyces bernardiae sp. nov.

\author{
GUIDO FUNKE, ${ }^{*}$ CRISTINA PASCUAL RAMOS, ${ }^{2}$ JOSÉ F. FERNÁNDEZ-GARAYZÁBAL, ${ }^{3}$
} NORBERT WEISS, ${ }^{4}$ AND MATTHEW D. COLLINS ${ }^{2}$ \\ Department of Medical Microbiology, University of Zürich, CH-8028 Zürich, Switzerland ${ }^{1}$; Department of Microbiology, BBSRC Institute of Food Research, Reading RG6 2EF, United Kingdom ${ }^{2}$; Departamento de Patologia Animal I, Facultad de Veterinaria, Universidad Complutense, E-28040 Madrid, Spain ${ }^{3}$; and Deutsche Sammlung von Mikroorganismen und Zellkulturen GmbH, D-38124 Braunschweig, Germany ${ }^{4}$
}

\begin{abstract}
Biochemical, chemotaxonomic, and molecular methods were used to establish the precise taxonomic position of the Centers for Disease Control (CDC) coryneform group 2 bacteria. The results of a comparative 16S rRNA sequence analysis demonstrated that the CDC coryneform group 2 bacteria constitute a distinct species within the genus Actinomyces. Actinomyces pyogenes was found to be the closest genealogical relative of the CDC coryneform group 2 bacteria, although these taxa were readily distinguished from each other and other Actinomyces spp. by using phenotypic criteria. On the basis of our findings we propose the name Actinomyces bernardiae sp. nov. for the CDC coryneform group 2 bacteria. The type strain is DSM 9152 (CCUG 33419).
\end{abstract}

Within the last few years, clinical microbiologists have become more aware of asporogenous, gram-positive rods as these bacteria have been encountered more frequently in clinical specimens. The taxonomic position of an individual strain, however, is often unclear $(8,27)$. In 1987, workers at the Special Bacteriology Reference Laboratory at the Centers for Disease Control and Prevention (CDC) designated some coryneform bacteria that were referred to this laboratory CDC coryneform group 2 bacteria (19). This taxon was established on the basis of morphological, biochemical, and chemical properties that separated its members from all previously described gram-positive rods (19). The initial 11 isolates belonging to $\mathrm{CDC}$ coryneform group 2 came from various clinical sources (e.g., blood, wounds, or the urinary tract). To our knowledge, no other report on CDC coryneform group 2 bacteria has appeared since the primary description of this taxon. As the precise taxonomic position of CDC coryneform group 2 was unclear, we conducted the study described below; in this study we used biochemical, chemotaxonomic, and molecular methods.

\section{MATERIALS AND METHODS}

Bacterial strains. The origins of the strains which we used and their clinical sources are shown in Table 1 . These strains were obtained from the National Laboratory for Bacteriology, Laboratory Center for Disease Control, Ottawa, Canada, from the Special Bacteriology Reference Laboratory, CDC, Atlanta, $\mathrm{Ga}$., and from the Department of Medical Microbiology, University of Zürich, Zürich, Switzerland.

Morphological and biochemical characteristics. Strains were grown aerobically at $37^{\circ} \mathrm{C}$ in an atmosphere containing $5 \% \mathrm{CO}_{2}$ on Columbia agar supplemented with 5\% sheep blood (all media were obtained from Becton Dickinson Microbiology Systems, Cockeysville, Md., unless indicated otherwise). The same medium was used to assess growth in a strictly anaerobic atmosphere (10). The methods used for biochemical profiling have been described previously (9). Commercial API ZYM (enzymatic profiling) and API 50CH (carbohydrate fermentation) systems (both obtained from API bioMérieux, Marcy l'Etoile, France) were used according to the instructions provided by the manufacturer.

Antimicrobial agent susceptibility testing. The MICs of eight antimicrobial agents (ciprofloxacin, clindamycin, erythromycin, gentamicin, penicillin G, ri-

* Corresponding author. Mailing address: Department of Medical Microbiology, University of Zürich, Gloriastrasse 32, CH-8028 Zürich, Switzerland. Phone: 41-1-257-2700. Fax: 41-1-252-8107. fampin, tetracycline, and vancomycin) were determined by the agar dilution method (Mueller-Hinton agar supplemented with 5\% sheep blood) according to the guidelines of the National Committee for Clinical Laboratory Standards (17, 18).

Gas-liquid chromatography. The method used to determine the end products of glucose metabolism has been described by Holdeman et al. (10). Cellular fatty acid patterns were generated by using the Microbial Identification System (Microbial ID, Inc., Newark, Del.) as described previously (26).

Cell wall analysis. Initially, whole-cell hydrolysates were screened for the presence of meso-diaminopimelic acid and mycolic acids by using the methods of Schaal (21). The peptidoglycan structure was determined by the method of Schleifer and Kandler (23), except that ascending thin-layer chromatography on cellulose sheets (Merck, Darmstadt, Germany) was used.

DNA base composition. DNA was isolated and purified by hydroxyapatite chromatography (5). The $\mathrm{G}+\mathrm{C}$ content was determined by the thermal denaturation method described by Mandel and Marmur (16)

Determination of the 16S rRNA gene sequence. Bacterial DNA was isolated by a standard minipreparation method, as described by Ausubel et al. (1). A large fragment of the 16S rRNA gene was amplified by the PCR by using universal primers $\mathrm{pA}$ (positions 8 to 28 ; Escherichia coli numbering [4]) and $\mathrm{pH}^{*}$ (positions 1542 to 1522 ) (3). The amplified product was sequenced directly by using primers for conserved regions of the rRNA gene and a Sequenase version 2.0 sequencing kit (United States Biochemical Corp., Cleveland, Ohio), as described by Hutson et al. (11). The rDNA sequences which we determined were aligned with the sequences of other high-G+C-content actinomycetes available in the EMBL Data Library. Levels of sequence similarity were calculated and used to derive nucleotide substitution rates corrected for transitions and transversions by using Kimura's parameters (13). An unrooted phylogenetic tree was constructed by using the neighbor-joining method (20).

Nucleotide sequence accession number. The nucleotide sequence of the $16 \mathrm{~S}$ rRNA gene of strain LCDC $89-0504^{\mathrm{T}}$ (= DSM $\left.9152^{\mathrm{T}}\right)(\mathrm{T}=$ type strain) has been deposited in the GenBank (EMBL) database under accession no. X79224.

TABLE 1. Origins of the strains studied

\begin{tabular}{|c|c|}
\hline Strain $^{a}$ & $\begin{array}{l}\text { Clinical diagnosis } \\
\text { or source }\end{array}$ \\
\hline \multicolumn{2}{|c|}{ CDC F507 } \\
\hline LCDC 88-0721 ... & Chest abscess \\
\hline LCDC 88-0770 ... & Ear abscess \\
\hline LCDC 89-0280. & Eye infection \\
\hline LCDC $89-0504^{\mathrm{T}}$. & Blood \\
\hline DMMZ $539 \ldots \ldots .$. & Blood \\
\hline DMMZ 1016... & Abscess \\
\hline
\end{tabular}

${ }^{a} \mathrm{CDC}$, Centers for Disease Control and Prevention, Atlanta, Ga.; LCDC, Laboratory Center for Disease Control, Ottawa, Canada; DMMZ, Department of Medical Microbiology, University of Zürich, Zürich, Switzerland. 
TABLE 2. Characteristics that differentiate $A$. bernardiae from other catalase-negative Actinomyces species ${ }^{a}$

\begin{tabular}{|c|c|c|c|c|c|c|c|c|c|}
\hline \multirow{2}{*}{ Species } & \multirow{2}{*}{$\begin{array}{l}\text { Beta-hemolysis on } \\
\text { sheep blood }\end{array}$} & \multirow{2}{*}{$\begin{array}{l}\text { Nitrate } \\
\text { reduction }\end{array}$} & \multirow{2}{*}{$\begin{array}{l}\text { Urease } \\
\text { activity }\end{array}$} & \multirow{2}{*}{$\begin{array}{l}\text { Esculin } \\
\text { hydrolysis }\end{array}$} & \multicolumn{5}{|c|}{ Fermentation of: } \\
\hline & & & & & Glucose & Maltose & Sucrose & Mannitol & Xylose \\
\hline A. bernardiae & $\mathrm{V}^{b}$ & - & - & - & + & + & - & - & - \\
\hline A. bovis & V & - & - & V & + & V & + & - & - \\
\hline A. georgiae & - & V & - & V & + & + & + & V & + \\
\hline A. gerencseriae & - & V & - & + & + & + & + & V & V \\
\hline A. hyovaginalis & - & + & - & + & + & + & + & ND & + \\
\hline A. israelii & - & V & - & + & + & + & + & V & + \\
\hline A. meyeri & - & - & $\mathrm{V}$ & - & + & V & + & - & + \\
\hline A. naeslundiic & - & $\mathrm{V}$ & $+^{d}$ & + & + & + & + & V & V \\
\hline A. odontolyticus & - & + & - & V & + & V & + & - & V \\
\hline A. pyogenes & + & - & - & - & + & V & V & V & + \\
\hline A. suis & V & - & + & - & - & $\mathrm{V}$ & - & - & - \\
\hline
\end{tabular}

${ }^{a}$ Data from references $7,12,15$, and 22 .

${ }^{b} \mathrm{~V}$, variable; +, positive; -, negative; ND, no data.

${ }^{c}$ Some strains have a positive catalase reaction.

${ }^{d}$ Often the reaction is weak or delayed.

\section{RESULTS AND DISCUSSION}

Three of the CDC coryneform group 2 strains which we studied were isolated from human blood cultures, and three strains came from abscesses of patients who were not linked epidemiologically (Table 1).

The CDC coryneform group 2 bacteria produced very small colonies when cells were grown under aerobic conditions in the presence of $5 \% \mathrm{CO}_{2}$. Growth occurred in a strictly anaerobic atmosphere, and these conditions did not influence colony size and appearance significantly. Colonies had glassy surfaces and entire edges. Gram staining revealed relatively short rods, some of which were clustered; filaments or branching was not observed. On the basis of the results obtained with a panel of biochemical tests (catalase, nitrate reduction, urea hydrolysis, and esculin hydrolysis, as well as fermentation of glucose, maltose, sucrose, mannitol, and xylose [14]), the CDC coryneform group 2 bacteria could clearly be separated from all previously described gram-positive taxa (19) (Table 2).

All of the strains tested were susceptible to clindamycin (MIC range, $\leq 0.03$ to $0.06 \mu \mathrm{g} / \mathrm{ml}$ ), erythromycin (MIC, $\leq 0.03$ $\mu \mathrm{g} / \mathrm{ml}$ ), penicillin $\mathrm{G}$ (MIC $\leq 0.03 \mu \mathrm{g} / \mathrm{ml}$ ), rifampin (MIC, $\leq 0.03 \mu \mathrm{g} / \mathrm{ml}$ ), tetracycline (MIC range, 0.125 to $0.25 \mu \mathrm{g} / \mathrm{ml}$ ), and vancomycin (MIC range, 0.06 to $0.125 \mu \mathrm{g} / \mathrm{ml}$ ). Most of the strains were susceptible to gentamicin (MIC range, 2 to 64 $\mu \mathrm{g} / \mathrm{ml}$ ) but resistant to ciprofloxacin (MIC range, 1 to $4 \mu \mathrm{g} / \mathrm{ml}$ ). The antimicrobial agent susceptibility test results are, therefore, consistent with the data obtained for other Actinomyces species by Schaal (22) and von Graevenitz et al. (27).

An analysis of the cellular fatty acid patterns revealed that
$\mathrm{C}_{16: 0}, \mathrm{C}_{18: 1 c i s 9}$, and $\mathrm{C}_{18: 0}$ were the major constituents (Table 3). This finding was consistent with the data published by $\mathrm{Na}$ 'was et al. (19) and Bernard et al. (2). Qualitatively, the pattern resembled the pattern obtained for some Corynebacterium spp. However, the CDC coryneform group 2 bacteria were readily distinguished from true corynebacteria because they lacked meso-diaminopimelic acid and mycolic acids (6). Additional evidence that the CDC coryneform group 2 bacteria are associated with the genus Actinomyces came from the observation that succinate was the major end product of glucose metabolism and from our peptidoglycan analysis. An analysis of partial peptidoglycan hydrolysates revealed that there was an L-alanine-L-lysine-D-glutamic acid (ratio, 3:2:2) interpeptide bridge. This unusual interpeptide bridge is present only in Actinomyces pyogenes (24) and Actinomyces suis (15). The $\mathrm{G}+\mathrm{C}$ contents of the chromosomal DNAs of the CDC coryneform group 2 strains were found to be 63 to $66 \mathrm{~mol} \%$, values which are within the range described for Actinomyces spp. (57 to $69 \mathrm{~mol} \%)(22)$.

In order to establish the phylogenetic position of the CDC group 2 coryneform bacteria, we determined the almost complete $16 \mathrm{~S}$ rRNA gene sequence of strain LCDC $89-0504^{\mathrm{T}}$. The primary structure of the derived 16S rRNA sequence of this strain is shown in Fig. 1; this sequence corresponds to approximately positions 40 to 1503 in the E. coli numbering system. The partial sequences (approximately 1,400 nucleotides) of two other strains (CDC F507 and LCDC 89-0280) were also determined and were found to be identical to the LCDC $89-0504^{\mathrm{T}}$ sequence, confirming the close genotypic relatedness

TABLE 3. Cellular fatty acid profiles of $A$. bernardiae strains $^{a}$

\begin{tabular}{|c|c|c|c|c|c|c|c|c|c|}
\hline \multirow{2}{*}{ Strain } & \multicolumn{9}{|c|}{$\%$ of total fatty acids ${ }^{b}$} \\
\hline & $\mathrm{C}_{10: 0}$ & $\mathrm{C}_{12: 0}$ & $C_{14: 0}$ & $\mathrm{C}_{16: 1 \text { cis } 9}$ & $C_{16: 0}$ & $C_{17: 0}$ & Feature $6^{c}$ & $\mathrm{C}_{18: 1 c i s 9}$ & $\mathrm{C}_{18: 0}$ \\
\hline CDC F507 & 1 & 1 & 4 & 2 & 25 & 1 & 4 & 36 & 18 \\
\hline LCDC 88-0601 & 1 & 1 & 3 & 2 & 34 & 1 & 7 & 24 & 16 \\
\hline LCDC $88-0721$ & 1 & 1 & 3 & 1 & 39 & 1 & 10 & 19 & 14 \\
\hline LCDC $88-0770$ & 2 & 1 & 7 & 3 & 27 & 1 & 3 & 33 & 15 \\
\hline LCDC 89-0280 & 2 & 2 & 11 & 5 & 40 & 1 & 6 & 21 & 13 \\
\hline${ }^{L C D C} 89-0504^{T}$ & 3 & & 7 & 3 & 41 & & 7 & 21 & 15 \\
\hline DMMZ 539 & 2 & 1 & 6 & 3 & 35 & 1 & 5 & 25 & 16 \\
\hline
\end{tabular}

${ }^{a}$ Values less than $1 \%$ are not reported.

${ }^{b}$ The number to the left of the colon is the number of carbon atoms, and the number to the right of the colon is the number of double bonds.

${ }^{c} \mathrm{C}_{18: 2 c i s 6,9}$ or $\mathrm{C}_{18: 0 a n t e i s o}$ (these fatty acids could not be separated). 
GGCGTGCTTAACACATGCAAGTCGAACGATGAAGCTACAGCTTCCTGTGGTGGATTAGTGGCGAACGGGTGAGTAATACGTGAGTAACCTGCCCTTGTCT TTGGGATAAGCCTGGGAAACTGGGTCTAATACCGGATATTCTGCTTTCATCGCATGGTGGGGGTTGGAAAGGGTTTCTGGATAGGGATGGGCTCACGGCC TATCAGCTTGTTGGTGGGGTGATGGCCTACCAAGGCGTCGACGGGTAGCCGGCCTGAGAGGGTGACCGGCCACATTGGGACTGAGATACGGCCCAGACTC CTACGGGAGGCAGCAGTGGGGAATATTGCACAATGGACGCAAGTCTGATGCAGCGACGCCGCGTGGGGGATGAAGGCTTTCGGGTTGTAAACTCCTTTCA GTACAGAACAAGGCCTTTTTGGTTGAGGGTATGTGCAGAAGAAGCGCCGGCTAACTACGTGCCAGCAGCCGCGGTAATACGTAGGGCGCGAGCGTTGTCC GGAATTATTGGGCGTAAAGAGCTCGTAGGCGGTTTGTTGCGCCTGCTGTGAAAGACCGGGGCTTAACTTCGGGGTTGCAGTGGGTACGGGCAGACTAGAG TGTGGTAGGGGTAATTGGAATTCCTGGTGTAGCGGTGGAATGCGCAGATATCAGGAGGAACACCGATGGCGAAGGCAGGTTACTGGGCCACCACTGACGC TGAGGAGCGAAAGCGTGGGTAGCGAACAGGATTAGATACCCTGGTAGTCCACGCCGTAAACGTTGGGCACTAGGTGTGGGGCCTTTTCCACGGGTTCTGC GCCGTAGCTAACGCATTAAGTGCCCCGCCTGGGGAGTACGGCCGCAAGGCTAAAACTCAAAGGAATTGACGGGGGCCCGCACAAGCGGCGGAGCATGCGG ATTAATTCGATGCAACGCGAAGAACCTTACCAAGGCTTGACATACACTGCGATGTGCCAGAGATGGTGCAGCCTTCGGGGTGGTGTACAGGTGGTGCATG GTTGTCGTCAGCTCGTGTCGTGAGATGTTGGGTTAAGTCCCGCAACGAGCGCAACCCTTGTCCTGTGTTGCCAGCAATTCGGTTGGGGACTCACGGGAGA CTGCCGGGGTTAACTCGGAGGAAGGTGGGGATGACGTCAAATCATCATGCCCCTTATGTCTTGGGCTTCACGCATGCTACAATGGCCGGTACAGAGGGTT GCGAGCCTGTGAGGGTGAGCTAATCTCTTAAAGCTGGTCTCAGTTCGGATTGGGGTCTGCAACTCGACCCCATGAAGTCGGAGTCGCTAGTAATCGCAGA TCAGCAACGCTGCGGTGAATACGTCCTCGGGCCTTGTACACACCGCCCGTCACGTCACGAAAGTTGGTAACACCCGAAGCCC

FIG. 1. Nucleotide sequence of the derived 16S rRNA of $A$. bemardiae sp. nov.

of the CDC coryneform group 2 strains. The $16 \mathrm{~S}$ rRNA gene sequence of LCDC 89-0504 ${ }^{\mathrm{T}}$ was compared with the sequences of other gram-positive bacteria available from the EMBL Data Library. The highest levels of sequence relatedness $(>88 \%)$ were found with species belonging to the genus Actinomyces. Figure 2 is a tree showing the position of the CDC coryneform group 2 bacteria within the genus Actinomyces; this tree was based on pairwise comparisons of approximately 1,300 nucleotides. About 100 nucleotides at the $5^{\prime}$ end of the rRNA were excluded from the similarity calculations used for tree construction because of incomplete sequence data for some Actinomyces spp. (25). Furthermore, potential alignment errors due to the hypervariable $\mathrm{V} 1$ region were avoided by this procedure. It was evident from both the levels of sequence similarity (Table 4) and the treeing program that the CDC coryneform group 2 bacteria were genealogically most closely related to $A$. pyogenes (level of similarity, approximately $97.5 \%$ when 1,350 bases were compared). However, the degree of divergence between these taxa (equivalent to 28 mismatches and 7 unmatched bases) is clearly consistent with the presence of two closely related but distinct species. Despite the relatively close genealogical affinity between the CDC coryneform group 2 bacteria and $A$. pyogenes, these taxa are easily distinguished by the inability of the former to ferment sucrose, mannitol, or xylose (Table 2). In addition, $A$. pyogenes colonies are larger and produce beta-hemolysis on sheep blood agar consistently. On the basis of the phenotypic, chemotaxonomic, and molecular results presented above we propose that the CDC coryneform group 2 bacteria should be classified in a new species of the genus Actinomyces, for which we propose the name Actinomyces bernardiae.

Actinomyces bernardiae sp. nov. Actinomyces bernardiae (ber. nar' di.ae. N.L. gen. n. bernardiae, of Bernard, named after contemporary Canadian microbiologist Kathryn A. Bernard for her contributions to the study of asporogenous, grampositive rods). The following description of morphological and physiological characteristics is based on the results of studies of seven strains (19; unpublished data).

Cells are gram-positive rods, with coccobacilli predominating. Cells are sometimes arranged in clusters, but primary branching is not observed. Cells are nonmotile and do not form spores. Colonies are circular, smooth, and slightly convex with a glassy appearance. Colony diameters range from 0.2 to 0.5 $\mathrm{mm}$ after $48 \mathrm{~h}$ of incubation in the presence of $5 \% \mathrm{CO}_{2}$ on sheep blood agar. Facultatively anaerobic. Catalase is not produced. Acid is produced from glycerol, ribitol, adonitol, D-glucose, D-fructose, maltose, starch, xylitol, D-arabitol, and 5-keto-gluconate. Most strains ferment erythritol, ribose, gly-

TABLE 4. Levels of 16S rRNA sequence similarity between Actinomyces bernardiae, other Actinomyces spp., and Arcanobacterium haemolyticum

\begin{tabular}{|c|c|c|c|c|c|c|c|c|c|}
\hline \multirow[b]{2}{*}{ Species or subspecies } & \multicolumn{9}{|c|}{$\%$ Similarity ${ }^{a}$} \\
\hline & 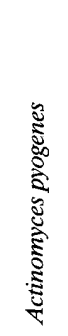 &  & 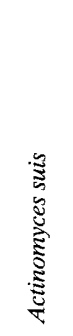 & 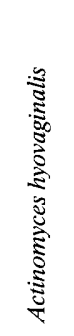 & 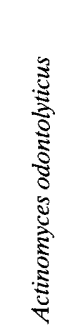 & 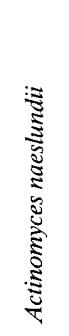 & 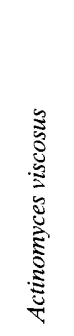 & 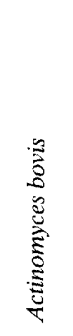 & 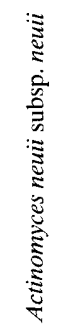 \\
\hline Actinomyces bernardiae & 98.1 & 93.8 & 92.1 & 88.5 & 89.1 & 89.4 & 89.2 & 88.7 & 89.0 \\
\hline Actinomyces pyogenes & & 94.3 & 91.9 & 89.4 & 89.7 & 89.7 & 89.4 & 88.6 & 88.9 \\
\hline Arcanobacterium haemolyticum & & & 89.5 & 88.4 & 89.1 & 88.7 & 88.6 & 88.7 & 88.5 \\
\hline Actinomyces suis & & & & 88.6 & 88.5 & 88.1 & 88.1 & 87.9 & 87.9 \\
\hline Actinomyces hyovaginalis & & & & & 95.4 & 90.2 & 90.5 & 90.9 & 89.6 \\
\hline Actinomyces odontolyticus & & & & & & 91.9 & 92.2 & 92.5 & 89.1 \\
\hline Actinomyces naeslundii & & & & & & & 98.1 & 95.1 & 88.6 \\
\hline Actinomyces viscosus & & & & & & & & 95.1 & 88.4 \\
\hline Actinomyces bovis & & & & & & & & & 88.3 \\
\hline
\end{tabular}

\footnotetext{
${ }^{a}$ Values are based on pairwise comparisons of ca. 1,300 nucleotides.
} 




FIG. 2. Unrooted tree constructed by the neighbor-joining method and based on a comparison of approximately 1,330 nucleotides, showing the phylogenetic interrelationships of $A$. bernardiae sp. nov., some other Actinomyces spp., and Arcanobacterium haemolyticum. Bar = approximately $1 \%$ divergence.

cogen, and L-arabitol. Acid is not produced from xylose, mannitol, $\alpha$-methyl-D-mannoside, amygdalin, arbutin, sucrose, and 2-keto-gluconate. Leucine arylamidase and $\alpha$-glucosidase positive. Alkaline phosphatase, cystine arylamidase, chymotrypsin, trypsin, acid phosphatase, $\alpha$-galactosidase, $\beta$-glucuronidase, $\beta$-glucosidase, $\alpha$-mannosidase, and $\alpha$-fucosidase negative. Esculin and urea are not hydrolyzed. Nitrate is not reduced. Palmitic and stearic acids are the main straight-chain cellular fatty acids, while oleic acid is the predominant unsaturated fatty acid. The interpeptide bridge within the peptidoglycan is L-alanine-L-lysine-D-glutamic acid (type A5 $\alpha$ ). The DNA base composition is 63 to $66 \mathrm{~mol} \% \mathrm{G}+\mathrm{C}$. Strains are isolated from various clinical sources, with blood and abscesses predominating. The habitat of the human-derived strains is not known. Type strain LCDC 89-0504 has been deposited in the Deutsche Sammlung von Mikroorganismen und Zellkulturen, Braunschweig, Germany, as strain DSM 9152 and in the Culture Collection of the University of Göteborg, Sweden, as strain CCUG 33419. The type strain possesses the characteristics described above for the species; the $\mathrm{G}+\mathrm{C}$ content of its DNA is $65 \mathrm{~mol} \%$.

\section{ACKNOWLEDGMENTS}

We thank A. von Graevenitz for critical reading of the manuscript. This work was supported by grants from Hartmann-Müller-Stiftung,

Zürich, Switzerland, EMDO-Stiftung, Zürich, Switzerland, and the European Community (Human Capital and Mobility Network).

\section{REFERENCES}

1. Ausubel, F. M., R. Brent, R. E. Kingston, D. D. Moore, J. G. Seidman, J. A. Smith, and K. Struhl. 1989. Current protocols in molecular biology. John Wiley \& Sons, Chichester, United Kingdom.

2. Bernard, K. A., M. Bellefeuille, and E. P. Ewan. 1991. Cellular fatty acid composition as an adjunct to the identification of asporogenous, aerobic gram-positive rods. J. Clin. Microbiol. 29:83-89.

3. Böddinghaus, B., J. Wolters, W. Heikens, and E. C. Böttger. 1990. Phylogenetic analysis and identification of six different serovars of Mycobacterium intracellulare at the molecular level. FEMS Microbiol. Lett. 70:197-204.

4. Brosius, J., M. L. Palmer, P. J. Kennedy, and H. F. Noller. 1978. Complete nucleotide sequence of a $16 \mathrm{~S}$ ribosomal RNA gene from Escherichia coli. Proc. Natl. Acad. Sci. USA 75:4801-4805.

5. Cashion, P., M. A. Holder-Franklin, J. McCully, and M. Franklin. 1977. A rapid method for the base ratio determination of bacterial DNA. Anal. Biochem. 87:461-466.

6. Collins, M. D., and C. S. Cummins. 1986. Genus Corynebacterium, p. 1266-1276. In P. H. A. Sneath, N. S. Mair, M. E. Sharpe, and J. G. Holt (ed.), Bergey's manual of systematic bacteriology, vol. 2. The Williams \& Wilkins Co., Baltimore.

7. Collins, M. D., S. Stubbs, J. Hommez, and L. A. Devriese. 1993. Molecular taxonomic studies of Actinomyces-like bacteria isolated from purulent lesions in pigs and description of Actinomyces hyovaginalis sp. nov. Int. J. Syst. Bacteriol. 43:471-473.

8. Coyle, M. B., and B. A. Lipsky. 1990. Coryneform bacteria in infectious diseases: clinical and laboratory aspects. Clin. Microbiol. Rev. 3:227-246.

9. Funke, G., G. Martinetti Lucchini, G. E. Pfyffer, M. Marchiani, and A. von Graevenitz. 1993. Characteristics of CDC group 1 and group 1-like coryneform bacteria isolated from clinical specimens. J. Clin. Microbiol. 31:29072912.

10. Holdeman, L. V., E. P. Cato, and W. E. C. Moore (ed.). 1977. Anaerobe laboratory manual, 4th ed. Department of Anaerobic Microbiology, Virginia Polytechnic Institute and State University, Blacksburg.

11. Hutson, R. A., D. E. Thompson, and M. D. Collins. 1993. Genetic interrelationships of saccharolytic Clostridium botulinum types $\mathrm{B}, \mathrm{E}$ and $\mathrm{F}$ and related clostridia as revealed by small-subunit rRNA gene sequences. FEMS Microbiol. Lett. 108:103-110.

12. Johnson, J. L., L. V. H. Moore, B. Kaneko, and W. E. C. Moore. 1990. Actinomyces georgiae sp. nov., Actinomyces gerencseriae sp. nov., designation of two genospecies of Actinomyces naeslundii, and inclusion of $A$. naeslundii serotypes II and III and Actinomyces viscosus serotype II in A. naeslundii genospecies 2. Int. J. Syst. Bacteriol. 40:273-286.

13. Kimura, M. 1980. A simple method for estimating evolutionary rates of base substitutions through comparative studies of nucleotide sequences. J. Mol. Evol. 16:110-120.

14. Krech, T., and D. G. Hollis. 1991. Corynebacterium and related organisms, p. 277-286. In A. Balows, W. J. Hausler, Jr., K. L. Herrmann, H. D. Isenberg, and H. J. Shadomy (ed.), Manual of clinical microbiology, 5th ed. American Society for Microbiology, Washington, D.C.

15. Ludwig, W., G. Kirchhof, M. Weizenegger, and N. Weiss. 1992. Phylogenetic evidence for the transfer of Eubacterium suis to the genus Actinomyces as Actinomyces suis comb. nov. Int. J. Syst. Bacteriol. 42:161-165.

16. Mandel, M., and J. Marmur. 1968. Use of ultraviolet absorbance-temperature profile for determining the guanine plus cytosine content of DNA. Methods Enzymol. 12B:195-206.

17. National Committee for Clinical Laboratory Standards. 1993. Methods for dilution antimicrobial susceptibility tests for bacteria that grow aerobically, 3rd ed., approved standard. Document M7-A3. National Committee for Clinical Laboratory Standards, Villanova, $\mathrm{Pa}$.

18. National Committee for Clinical Laboratory Standards. 1993. Minimum inhibitory concentration (MIC) interpretative standards $(\mu \mathrm{g} / \mathrm{ml})$ for organisms other than Haemophilus, Neisseria gonorrhoeae, and Streptococcus pneumoniae. Document M7-A3. National Committee for Clinical Laboratory Standards, Villanova, $\mathrm{Pa}$.

19. Na'was, T. E., D. G. Hollis, C. W. Moss, and R. E. Weaver. 1987. Comparison of biochemical characteristics of Centers for Disease Control fermentative coryneform groups 1, 2, and A-4. J. Clin. Microbiol. 25:1354-1358.

20. Saitou, N., and M. Nei. 1987. The neighbor-joining method: a new method for reconstructing phylogenetic trees. Mol. Biol. Evol. 4:406-425.

21. Schaal, K. P. 1985. Identification of clinically significant actinomycetes and related bacteria using chemical techniques, p. 359-381. In M. Goodfellow and D. E. Minnikin (ed.), Chemical methods in bacterial systematics. Academic Press, London.

22. Schaal, K. P. 1986. Genus Actinomyces, p. 1383-1418. In P. H. A. Sneath, N. S. Mair, M. E. Sharpe, and J. G. Holt (ed.), Bergey's manual of systematic bacteriology, vol. 2. The Williams \& Wilkins Co., Baltimore.

23. Schleifer, K. H., and O. Kandler. 1972. Peptidoglycan types of bacterial cell walls and their taxonomic implications. Bacteriol. Rev. 36:407-477.

24. Schleifer, K. H., and P. H. Seidl. 1985. Chemical composition and structure of murein, p. 201-219. In M. Goodfellow and D. E. Minnikin (ed.), Chemical methods in bacterial systematics. Academic Press, London.

25. Stackebrandt, E., and O. Charfreitag. 1990. Partial 16S rRNA primary structure of five Actinomyces species: phylogenetic implications and development of an Actinomyces israelii-specific oligonucleotide probe. J. Gen. Microbiol. 136:37-43.

26. von Graevenitz, A., G. Osterhout, and J. Dick. 1991. Grouping of some clinically relevant gram-positive rods by automated fatty acid analysis. APMIS 99:147-154.

27. von Graevenitz, A., V. Pünter, E. Gruner, G. E. Pfyffer, and G. Funke. 1994. Identification of coryneform and other gram-positive rods with several methods. APMIS 102:381-389. 